\title{
Peningkatan Hasil Belajar IPA Melalui Penerapan Model Pembelajaran Cooperatif Type Make A Match Pada Murid Kelas IV SDN Bayang Kecamatan Tamalate Kota Makassar
}

\author{
Muh Khaedar ${ }^{1^{*}}$, R. Supardi ${ }^{2}$, Syamsul Alam ${ }^{3}$ \\ ${ }^{1}$ Prodi PGSD/Universitas Mega Rezky Makassar \\ Email: khaedarmuh@yahoo.co.id \\ ${ }^{2}$ Prodi PGSD/Universitas Mega Rezky Makassar \\ Email: rsupardiNatsir3@gmail.com \\ ${ }^{3}$ Prodi PGSD/Universitas Mega Rezky Makassar \\ Email:syamsulalamraja@yahoo.co.id
}

\begin{abstract}
Peningkatan Hasil Belajar IPA Melalui Penarapan Model Pembelajaran Cooperatif Type Make A Match, fokus penelitian Pada Murid Kelas IV SDN Bayang Kecamatan Tamalate Kota Makassar hal ini dibuktikan nilai awal yang didapat siswa sebelum penelitian adalah 20\% siswa memperoleh ketuntasan belajar. Adapun tujuan penelitian ini untuk meningkatkan hasil pembelajaran IPA melalui penerapan model pembelajaran cooperatif type make a match pada murid kelas IV SDN Bayang Kecamatan Tamalate Kota Makassar. Pendekatan yang digunakan yaitu pendekatan kualitatif dengan rancangan penelitian tindakan. Rancangan penelitian ini di susun dengan satuan siklus secara berdaur ulang berulang meliputi (1) perencanaan, (2) pelaksanaan, (3) observasi, (4) refleksi. Bentuk pembelajaran yang diyakini dapat meningkatakan kemampuan murid adalah suatu bentuk pembelajaran yang menggunakan model pembelajaran cooperatif type make a match terdiri atas (1) tahap pembangkitan semangat belajar, (2) tahap pambagian kelompok, (3) tahap ekplorasi dengan bertukar pikiran antar sesama siswa dan guru, (4) tahap mengaitkan pembelajaran dengan realitas kenyataan lingkungan siswa (5) tahap kesimpulan (6) tahap penilaian. Hasil penelitian menunjukkan bahwa penggunaan model pembelajaran cooperatif type make a match yang terdiri dari enam tahap yaitu (1) tahap pembangkitan semangat belajar, (2) tahap pambagian kelompok, (3) tahap ekplorasi dengan bertukar pikiran antar sesama siswa dan guru, (4) tahap mengaitkan pembelajaran dengan realitas kenyataan lingkungan siswa, (5) tahap kesimpulan (6) tahap penilaian.
\end{abstract}

Kata kunci: Peningkatan Hasil Belajar IPA; Model Pembelajaran; Cooperatif Type Make A Match.

\section{PENDAHULUAN}

Keberhasilan program pendidikan melalui proses belajar mengajar di sekolah sebagai lembaga pendidikan formal sangat dipengaruhi oleh beberapa faktor antara lain: siswa, kurikulum, tenaga kependidikan, biaya, sarana dan prasarana serta faktor lingkungan. Apabila faktor-faktor tersebut dapat terpenuhi sudah tentu akan memperlancar proses belajar-mengajar sehingga menunjang pencapaian hasil belajar yang maksimal.

Berbagai upaya telah dilakukan untuk meningkatkan mutu pendidikan di sekolah, antara lain dengan perbaikan mutu belajarmengajar. Belajar mengajar di sekolah merupakan serangkaian kegiatan yang dilakukan secara sadar dan terencana. Dengan adanya perencanaan yang baik akan mendukung keberhasilan pengajaran. Usaha perencanaan 
pengajaran diupayakan agar peserta didik memiliki kemampuan maksimal.

Mata pelajaran IPA di Sekolah Dasar merupakan salah satu program pembelajaran yang bertujuan untuk mengembangkan rasa ingin tahu anak, sikap positif dan kesadaran tentang adanya hubungan yang saling mempengaruhi antara sains, lingkungan teknologi dan serta dapat memecahkan masalah dan membuat keputusan yang berhubungan dengan kehidupan sehari-hari. Selanjutnya Abruscato (Khaeruddin dan Sujiono, 2005:15) yang menyatakan bahwa "Sains diajarkan di kelas dapat: 1) mengembangkan kognitif Murid, 2) mengembangkan afektif Murid, 3) mengembangkan psikomotorik Murid, 4) mengembangkan kreatifitas Murid 5) melatih Murid berpikir kritis". Kelima alasan tersebut sangat sesuai dengan tujuan pembelajaran di kelas, yaitu mengembangkan kognitif, afektif, dan psikomotorik Murid.

Salah satu kendala utama dalam proses belajar mengajar adalah kurangnya antusias peserta didik untuk belajar peserta didik lebih cenderung menerima apa saja yang disampaikan oleh guru, diam dan enggan mengemukakan pertanyaan maupun pendapat. Hal ini dikarenakan pembelajaran yang dilakukan oleh guru cenderung menggunakan metode pembelajaran konvensional yakni ceramah, tanya jawab dan pemberian tugas. Padahal dalam kerangka pembelajaran IPA, peserta didik mesti dilibatkan secara mental, fisik dan sosial untuk dapat mengembangkan kognitif, afektif, psikomotorik, kreativitas serta melatih siswa dalam berpkir kritis dalam memahami fenomena-fenomena yang terjadi di alam atau peristiwa-peristiwa yang terjadi di lingkungan sekitar sehingga dapat memecahkan masalah tentang isu-isu sosial dalam masyarakat yang menjadi tantangan hidup dan mampu mengambil keputusan dalam menyelesaikan masalah tersebut. Jika hal ini tidak tercakup dalam proses pembelajaran dapat dipastikan penguasaan konsep IPA akan kurang. Berdasarkan informasi dari wali kelas IV di SDN Bayang Kecamatan Tamalate Kota Makassar pada tanggal 5 September 2011, peneliti memperoleh data sebagai berikut: pembelajaran cenderung berpusat pada guru, guru mengambil peran dominan di dalam kelas karena guru yang aktif menyampaikan materi pembelajan, metode ceramah yang dominan dilakukan oleh guru mengakibatkan siswa cenderung berlaku pasif. Hal ini ditunjukkan dengan beberapa sikap siswa yang nampak pada saat proses belajar mengajar. Respon yang ditunjukkan oleh siswa antara lain: banyak murid yang bermain-main, siswa sulit berkonsentrasi selama pelajaran berlangsung, banyak siswa yang melakukan kegiatan sendiri atau bersama teman saling bercerita. Sehingga terungkap bahwa nilai rata-rata hasil belajar IPA siswa berada dalam kategori rendah yaitu ratarata 60,00 masih dibawah KKM (Kriteria Ketuntasan Minimal) yang ditetapkan di sekolah tersebut yaitu 65 sehingga masih perlu ditingkatkan. Dari 37 siswa hanya 12 siswa yang mendapat nilai diatas rata-rata atau $32,4 \%$ yang nilainya sesuai dengan KKM yang telah ditentukan sedangkan 25 siswa masih dibawah rata-rata atau $67,6 \%$ masih belum sesuai dengan KKM yang telah ditentukan.

Rendahnya pencapaian nilai akhir siswa ini, menjadi indikasi bahwa pembelajaran yang dilakukan selama ini belum efektif. Nilai akhir dari evaluasi belajar belum mencakup penampilan dan partisipasi siswa dalam pembelajaran, hingga sulit untuk mengukur keterampilan siswa. Salah satu alternatif untuk mengatasi masalah yang ada berupa penerapan model pembelajaran yang lebih mengutamakan keaktifan peserta didik dan memberi kesempatan peserta didik untuk mengembangkan potensinya secara maksimal. Model pembelajaran yang dimaksud adalah model pembelajaran kooperatif.

Model pembelajaran kooperatif tumbuh dari suatu tradisi pendidikan yang menekankan berpikir dan latihan bertindak demokratis, pembelajaran aktif, perilaku kooperatif, dan menghormati perbedaan dalam masyarakat multibudaya. Dalam pelaksanaannya pembelajaran kooperatif dapat merubah peran guru dari peran terpusat pada guru ke peran pengelola aktivitas kelompok kecil. Sehingga dengan demikian peran guru yang selama ini monoton akan berkurang dan peserta didik akan semakin terlatih untuk menyelesaikan berbagai permasalahan, bahkan permasalahan yang dianggap sulit sekalipun. Beberapa peneliti yang terdahulu yang menggunakan model pembelajaran kooperatif menyimpulkan bahwa model pembelajaran tersebut telah memberikan masukan yang berarti bagi sekolah, guru dan terutama peserta didik dalam meningkatkan prestasi.

Terdapat berbagai tipe pembelajaran kooperatif, satu diantaranya adalah tipe make a match. Tipe 
make a match merupakan salah satu alternatif yang dapat diterapkan kepada peserta didik. Penerapan tipe ini dimulai dari teknik yaitu guru menyiapkan kartu soal dan kartu jawaban, kemudian peserta didik dibagi dalam kelompok kecil, setelah itu setiap kelompok menerima satu paket kartu soal/ kartu jawaban, kartu dikocok

\section{METODE}

\section{Setting Penelitian}

Tempat Penelitian ini dilaksanakan di SDN Bayang Kecamatan Tamalate Kota Makassar. Subjek penelitian ini adalah seluruh siswa kelas IV SDN Bayang Kecamatan Tamalate Kota Makassar. Dengan jumlah murid 37 orang. 14 laki-laki, dan 23 perempuan. Waktu Penelitian ini dilaksanakan pada semester ganjil tahun ajaran 2011/2012. Penentuan waktu penelitian mengacu pada kalender akademik sekolah, karena penelitian ini memerlukan beberapa siklus yang membutuhkan proses belajar mengajar di kelas.Siklus penelitian ini terbagi atas II siklus, setiap siklus $4 \mathrm{X}$ pertemuan.

\section{Persiapan Penelitian}

Sebelum penelitian dilaksanakan berbagai input instrumental yang akan digunakan yaitu:

1. Rencana Pelaksanaan Pembelajaran ( RPP )

2. Lembar Kerja Murid ( LKM)

3. Lembar Pengamatan Murid ( kerja sama dan Komunikasi )

4. Lembar Evaluasi

5. Daftar nama-nama murid.

\section{Subjek Penelitian}

Subjek penelitian ini adalah siswa kelas IV SDN Bayang Kecamatan Tamalate Kota Makassar sebanyak 37 orang. 14 laki-laki, dan 23 perempuan semester ganjil tahun ajaran $20011 / 2012$.

\section{Sumber Data}

1. Murid

Untuk mendapatkan data tentang aktivitas dan hasil belajar murid dalam proses belajar mengajar.

2. Guru

Untuk melihat tingkat keberhasilan implementasi pembelajaran model kooperatif tipe make a match untuk meningkatkan hasil belajar murid dalam proses pembelajaran. kemudian dibagikan pada setiap anggota kelompok, setiap anggota kelompok memikirkan dan mencari pasangan dari kartu yang diambilnya sebelum batas waktunya, peserta didik yang dapat mencocokkan kartunya diberi poin.

\section{Teknik Dan Alat Pengumpulan Data}

1. Sumber Data

Sumber data dalam Penelitian Tindakan Kelas ini adalah siswa kelas IV SDN Bayang Kecamatan Tamalate Kota Makassar.

2. Jenis Data

Data yang diperoleh dari suatu sumber data berupa data kuantitatif dan kualitatif yang diperoleh melalui:

a. Tes hasil belajar IPA tiap akhir siklus

b. Lembar observasi, dan

c. Lembar respon/tanggapan siswa

3. Cara Pengumpulan Data

Adapun cara pengumpulan data pada penelitian ini adalah sebagai berikut:

a. Data tentang kemampuan awal siswa diperoleh dari hasil belajar IPA siswa pada pokok bahasan sebelumnya.

b. Data hasil belajar IPA diperoleh dengan memberikan tes uraian pada setiap akhir siklus.

c. Data tentang aktivitas belajar siswa diperoleh dengan menggunakan lembar observasi.

d. Data tentang refleksi diperoleh dengan memberikan lembar respon/tanggapan siswa terhadap pembelajaran IPA.

\section{Indikator Kinerja}

Indikator kinerja yang menunjukkan keberhasilan pelaksanaan Penelitian Tindakan Kelas (Classroom Action Research) ini adalah adanya peningkatan skor rata-rata belajar IPA siswa setiap siklus setelah pembelajaran model make a match diterapkan. Indikator keberhasilan Penelitian Tindakan Kelas (Classroom Action Research) ini adalah terjadinya peningkatan hasil belajar siswa yang ditinjau dari meningkatnya skor rata-rata atau mean dari siklus I ke siklus II yang dapat dilihat dari hasil tes siklus siswa yaitu untuk individu $65 \%$ dan skor ketuntasan kelas yaitu $85 \%$ dari siswa yang memperoleh skor minimal $65 \%$ dari skor ideal yang sesuai dengan Kriteria Ketuntasan Minimum (KKM). 


\section{Analisis Data}

Data yang diperoleh dari hasil penelitian dianalisis secara kualitatif dan kuantitatif. Data hasil observasi dianalisis secara kualitatif sedangkan hasil belajar siswa dianalisis secara kuantitatif dengan menggunakan analisis data deskriptif. Data hasil belajar dikategorikan dengan menggunakan teknik kategorisasi standar yang ditetapkan oleh Departemen Pendidikan Nasional (Fahrul, 2007:37) yaitu sebagai berikut:

Tabel 1. Teknik kategori standar berdasarkan ketetapan Depdiknas

\begin{tabular}{ccc}
\hline No & Nilai & Kategori \\
\hline 1 & $00-34$ & Sangat Rendah \\
\hline 2 & $35-54$ & Rendah \\
\hline 3 & $55-64$ & Sedang \\
\hline 4 & $65-84$ & Tinggi \\
\hline 5 & $85-100$ & Sangat Tinggi \\
\hline
\end{tabular}

\section{Prosedur Penelitian}

Menurut Suharsimi dan Arikunto, (2006:16) prosedur penelitian tindakan ini tampak pada alur pelaksanaan tindakan berikut ini:
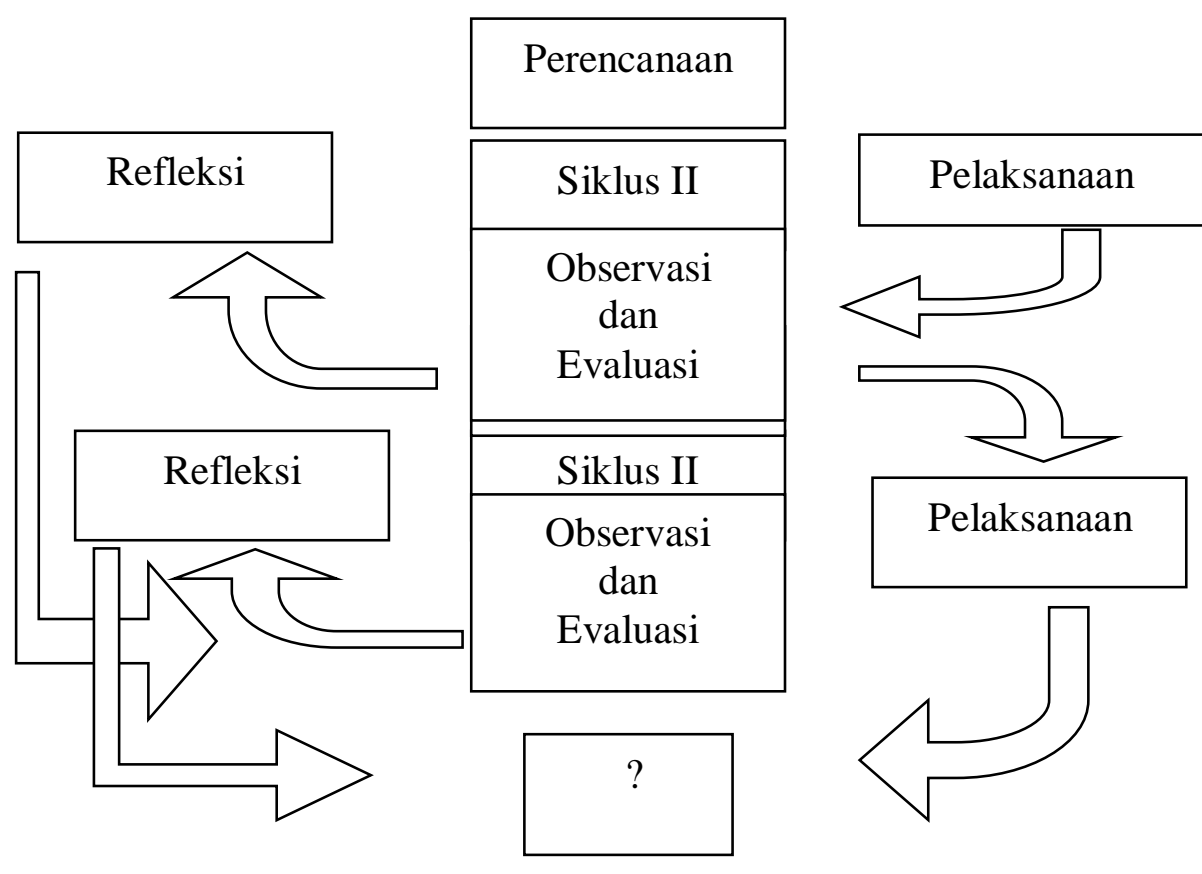

Penelitian tindakan kelas ini dilakukan dengan menggunakan siklus, siklus ini merupakan rangkaian kegiatan yang saling berkaitan. Berikut gambaran umum pelaksanaan penelitian pada siklus awal.

\section{Gambaran umum siklus awal}

Langkah awal yang akan dilakukan pada siklus ini adalah menyiapkan materi pelajaran yang akan diajarkan.

1. Perencanaan Tindakan.

Adapun kegiatan yang akan dilakukan tahap perencanaan:

a. Menelaah kurikulum SD kelas V semester genap pada mata pelajaran IPA.

b. Membuat perangkat pembelajaran setiap peretemuan yang terdiri dari rencana pelaksanaan pembelajaran (RPP) dan lembar kegiatan Murid (LKM).

2. Observasi Dan Evaluasi

Selama proses pembelajaran dilaksanakan pengamatan tentang kondisi pembelajaran baik itu pada siswa maupun pada guru menggunakan lembar observasi yang telah dibuat. Dalam pelaksanaan observasi ini, guru dibantu oleh seorang observer. Sedangkan data evaluasi diperoleh dengan melihat hasil latihan mandiri, PR, dan tes hasil belajar IPA siswa pada akhir siklus I. tanggapan atau saran siswa mengenai pembelajaran kooperatif tipe make a match juga merupakan sumber informasi yang berharga dalam mengevaluasi pelaksanaan pembelajaran. 
3. Refleksi

Hasil yang didapat pada tahap observasi dan evaluasi, baik secara kuantitatif maupun secara kualitatif, dikumpulkan dan dianalisis untuk dijadikan bahan pemikiran dalam merefleksi kegiatan selama tindakan dilakukan. Dari hasil refleksi ini, guru mengetahui hal-hal yang masih perlu dibenahi dan untuk selanjutnya diterapkan pada siklus berikutnya. Hasil ini menjadi acuan untuk merencanakan siklus selanjutnya yang diharapkan memberikan hasil yang lebih baik dari siklus awal, dan tentunya tetap mempertahankan hal-hal yang sudah dianggap baik pada siklus I.

Jika pada siklus awal/siklus I tidak tercapai maka dilakukan siklus berikutnya/siklus II.

\section{Gambaran umum siklus II}

Sebagaimana halnya siklus I, siklus II juga berlangsung selama 4 kali pertemuan.

a. Tindakan Perencanaan

a. Melanjutkan tahap perencanaan yang telah dilakukan pada siklus I.

b. Dari hasil refleksi pada siklus I, guru menyusun rencana baru untuk ditindak lanjuti, antara lain mengawasi siswa lebih tegas lagi dan memberikan arahan atau motivasi kepada Murid yang kurang memperhatikan pelajaran atau tidak aktif.

b. Pelaksanaan Tindakan

Tindakan siklus II ini adalah melanjutkan langkah-langkah yang telah dilakukan pada siklus I dan beberapa perbaikan yang dianggap perlu dalam memecahkan masalah yang muncul pada siklus sebelumnya. Tindakan yang perlu dilakukan adalah:

a. Melanjutkan tindakan model pembelajaran kooperatif.

b. Siswa yang mengalami kesulitan dalam menyelesaikan tugas diberikan bimbingan secara lansung.

c. Observasi dan Evaluasi

Tahap observasi siklus II ini adalah melanjutkan kegiatan pada siklus I yang dilaksanakan pada saat proses belajar mengajar

d. Refleksi

Pada tahap refleksi umumnya langkahlangkah yang dilakukan pada siklus II seperti halnya yang dilakukan pada siklus I, yaitu: a. Menilai dan mengamati perkembangan hasil belajar siswa dan nilai tes akhir siklus II.

b. Mengamati dan mencatat perkembangan-perkembangan atau halhal yang dialami oleh siswa selama berlansungnya proses belajar mengajar.

c. Menarik beberapa kesimpulan dari hasil analisis refleksi dan keseluruhan data yang telah diperoleh selama dua siklus.

\section{Indikator Keberhasilan}

Indikator Keberhasilan penelitian tindakan kelas ini adalah kemungkinan skor rata-rata hasil tes murid melalaui penerapan pembelajaran kooperatif tipe make a match mengalami peningkatan secara klasikal mencapai $70 \%$ dan terjadi perubahan sikap murid selama mengikuti proses pembelajaran yang ditandai dengan peningkatan keaktifan murid dalam hal mengemukakan pendapat, menjawab pertanyaan dan tanggung jawab dalam proses pembelajaran.

\section{HASIL DAN PEMBAHASAN}

Tabel 2. Statistik Skor Hasil Belajar murid Kelas IV SDN Bayang Kecamatan Tamalate Kota Makassar Siklus I

\begin{tabular}{lc}
\hline \multicolumn{1}{c}{ Statistik } & Nilai Statistik \\
\hline Jumlah Murid & 33 \\
\hline Skor Ideal & 100 \\
\hline Nilai Maksimum & 90 \\
\hline Nilai Minimum & 30 \\
\hline Rentang Skor & 60 \\
\hline Skor Rata-Rata & 55,16 \\
\hline Median & 60 \\
\hline Modus & 60 \\
\hline Standar Deviasi & 10,25 \\
\hline Jumlah Murid & 33 \\
\hline
\end{tabular}

Tabel 3. Statistik Skor Hasil Belajar murid Kelas IV SDN Bayang Kecamatan Tamalate Kota Makassar Siklus II.

\begin{tabular}{lc}
\hline \multicolumn{1}{c}{ Statistik } & Nilai Statistik \\
\hline Jumlah Murid & 33 \\
\hline Skor Ideal & 100 \\
\hline Nilai Maksimum & 100 \\
\hline Nilai Minimum & 60 \\
\hline Rentang Skor & 40 \\
\hline Skor Rata-Rata & 73,19 \\
\hline
\end{tabular}




\begin{tabular}{lc}
\hline Median & 70 \\
\hline Modus & 60 \\
\hline Standar Deviasi & 5,75 \\
\hline
\end{tabular}

\section{SIMPULAN DAN SARAN}

Berdasarkan hasil analisis data dan pembahasan maka dapat ditarik kesimpulan bahwa Pembelajaran kooperatif tipe make a match cocok digunakan di kelas tersebut. Hal tersebut dapat dilihat dari meningkatnya hasil belajar murid kelas IV SDN Bayang Kecamatan Tamalate Kota Makassar setelah diadakan pengembangan pembelajaran kooperatif tipe make a match. Hasil belajar yang diperoleh dari tes akhir siklus, pada akhir siklus I dengan skor rata-rata 55,15 dari skor ideal 100 sedangkan pada akhir siklus II dengan skor rata-rata 73,18 dari skor ideal 100. Terjadi perubahan sikap murid selama proses pembelajaran sesuai dengan hasil observasi yaitu dengan adanya penerapan model pembelajaran kooperatif tipe make a match dapat meningkatkan rasa percaya diri murid untuk bertanya kepada guru dan dapat meningkatkan kehadiran siswa. Kuantitas bukubuku perpustakaan, sehingga murid. yang tidak memiliki buku pelajaran belajarnya tidak terhambat dengan meminjam keperpustakaan. Diharapkan kepada peneliti yang akan melakukan penelitian sebaiknya mengambil satu permasalahan misalnya kombinasi antara model pembelajaran kooperatif tipe make a match ini dengan salah satu metode pembelajaran, untuk mengetahui apa dengan penerapannya dapat meningkatkan hasil belajar murid.

Berdasarkan hasil yang diperoleh dari penelitian ini, maka penulis mengajukan beberapa saran kepada guru IPA khususnya agar dapat mencoba menerapkan model pembelajaran kooperatif tipe make a match dalam proses belajar mengajar agar dapat meningkatkan hasil belajar murid. Guru IPA sebaiknya kreatif dalam menciptakan suasana kelas agar murid tidak cepat bosan dan tegang dalam belajar serta lebih termotivasi untuk memperhatikan apa yang diajarkan.

\section{DAFTAR RUJUKAN}

Arikunto, Suharsimi. 2009. Penelitian Tindakan Kelas. Jakarta: Bumi Aksara.
Dimyanti.2007. Belajar Dan Pembelajaran. Jakarta: Rineka Cipta.

Fahrul. 2007. Meningkatkan Hasil Belajar Matematika Siswa Kelas V SD Inpres Batua II Bertingkat Makassar Melalui Penerapan Pembelajaran Kooperatif Tipe Numbered Head Together. Skripsi UNISMUH Makassar.

Haling, Abdul. 2007. Belajar dan Pembelajaran. Makassar: Badan Penerbit UNM.

Ibrahim, Muslim. 2005. Belajar dan Pembelajaran. Makassar: Badan Penerbit UNM.

Kasim Ratna. 2008. Materi dan Pembelajaran IPA. Makassar: Program S1 PGSD Unismuh Makassar.

Khaeruddin, Sujiono, E.H.2005. Pembelajaran Sains (IPA) Berdasarkan Kurikulum Berbasis Kompetensi. Makassar: Badan Penerbit Makassar.

Kristiawati. 2009. Meningkatkan Hasil Belajar Matematika Melalui Penerapan Pembelajaran Kooperatif Tipe Make A Match Pada Siswa Kelas VII SMP Muhammadiyah 5 Makassar. Skripsi Unismuh Makassar.

Kunandar. 2010. Langkah Mudah Penelitian Tindakan Kelas Sebagai Pengembangan Profesi Guru. Jakarta: Rajawali Pers.

Ramadhan, Tarmizi. 2008. pembelajaran kooperatif "make a match". Artikel (http://tarmizi.wordpress.com/2008/12/0 3/pembelajaran-kooperatif-make-amatch/). Diakses 3 Oktober 2010.

Ratumanan. 2004. Belajar dan Pembelajaran. Ambon: Unesa University Press.

Rusman. 2010. Model-Model Pembelajaran. Jakarta: PT. Rajagrafindo Persada.

Sanjana Wina.2009. Penelitian Tindakan Kelas. Jakarta: Kencana Prenada Media Group. 